\title{
Original Paper / Artigo Original Marine microalgae on the southern coast of Bahia, Brazil: composition and new records of phytoplankton species
}

\author{
Helen Michelle de Jesus Affe ${ }^{1,2}$, Lorena Petersen Nascimento Santos ${ }^{1}$, Márcio Ferreira dos Santos ${ }^{1}$ \\ $\&$ José Marcos de Castro Nunes ${ }^{1}$
}

\begin{abstract}
The phytoplankton community is the first link in the aquatic trophic chain and knowledge of its composition is an important tool for ecological characterization; including as potential indicator of anthropic impacts. The southern coast of Bahia is one of the best preserved parts of the Brazilian coast, however, little is known about its biodiversity, especially on marine phycoflora. With the objective of characterizing the composition of microphytoplankton $(>20 \mu \mathrm{m})$ in this region, samples were collected by a horizontal dredger using a plankton net ( $20 \mu \mathrm{m}$ mesh size) to study the community composition. Water samples were taken from the subsurface using a Van Dorn bottle in order to analyze phytoplanktonic cell concentration. A total of 149 taxa were identified, distributed in the following phyla: Bacillariophyta, Miozoa, Cyanobacteria, Euglenophyta, Haptophyta, and Ochrophyta. Diatoms (63\%) and dinoflagellates $(26 \%)$ were the most representative groups in the specific composition. 43 new taxonomic occurrences were recorded for the coasts of Bahia, Northeastern Brazilian coast, and Brazilian coast.
\end{abstract}

Key words: marine phycoflora; microphytoplankton; Bacillariophyta.

\section{Resumo}

A comunidade fitoplanctônica representa o primeiro elo na cadeia trófica aquática e o conhecimento de sua composição é uma ferramenta importante para a caracterização ecológica de um sistema. Inclusive como indicador potencial de impactos antrópicos na água. O litoral sul da Bahia é um dos segmentos da costa brasileira em melhor estado de preservação ambiental, ainda conhecendo-se muito pouco à respeito da sua biodiversidade, especialmente a ficoflora marinha. Com o objetivo de caracterizar a composição do microfitoplâncton $(>20 \mu \mathrm{m})$ nesta região, foram coletadas amostras, em arrastos horizontais de subsuperfície, utilizando-se rede de plâncton (20 $\mu \mathrm{m}$ de malha) para estudar a composição da comunidade. Amostras de água foram coletadas com garrafa de Van Dorn, para analisar a densidade celular do microfitoplâncton. Foram identificados um total de 149 taxa, distribuídos nos filos: Bacillariophyta, Miozoa, Cianobacteria, Euglenophyta, Haptophyta e Ochrophyta. As diatomáceas (63\%) e os dinoflagelados (26\%) foram os grupos mais representativos na composição específica e 43 novas occorrências taxonômicas foram registradas para a costa da Bahia, litoral do Nordeste e litoral do Brasil.

Palavras-chave: ficoflora marinha; microfitoplâncton; Bacillariophyta.

\section{Introduction}

The phytoplankton community is the first link in the aquatic trophic chain (Reynolds 2006) and knowledge of its composition is an important tool for the ecological characterization of coastal ecosystems (Eskinazi-Leça et al. 2004; Cloern \&
Jassby 2010); including the potential as indicator of anthropic impacts.

The largest part of the Brazilian coast can be found in the Northeast. Although it is one of the regions with the highest diversity of microalgae (Menezes et al. 2015), it remains with many coastal

See supplementary material at <https.//doi.org/10.6084/m9.figshare.9759311.v1>

${ }^{1}$ Universidade Federal da Bahia (UFBA), Inst. Biologia, Lab. Algas Marinhas (LAMAR), R. Barão de Jeremoabo s/n, Ondina, 40170-115, Salvador, BA, Brazil.

${ }^{2}$ Author for correspondence: helenmaffe@gmail.com 
environments still to be inventoried. In the case of Bahia, which comprises the most extensive part of the Brazilian coast, little is known about phytoplankton communities; most published studies are concentrated in the Todos os Santos Bay (e.g., Peixinho et al. 1980; Cowgill 1987; Mafalda Jr. et al. 2003; Magalhães \& Barbosa 2008) and Camamu Bay (i.e., Affe \& Santana 2016; Santana \& Affe 2016). Nevertheless, most studies are not published as research articles and can only be found in academic monographs and dissertations.

Although it is an important touristic destination $(\sim 162,222$ people in 2009, Baiardi \& Teixeira 2010), southern Bahia is one of the parts of the Brazilian coast with a better state of environmental preservation. Nonetheless, little is known about its biodiversity, especially on marine phycoflora. The region has two areas of environmental protection (APAs, from the Portuguese acronym): the APA Tinharé-Boipeba (State Decree No. 1,240 of June $\left.5^{\text {th }}, 1992\right)$, comprising mangroves of great fishing potential and beaches of great touristic appeal; and the APA Baía de Camamu (State Decree n 8.175 of February $27^{\text {th }}, 2002$ ), where the fourth largest bay in Brazil can be found. Both are often affected by conflicts such as deforestation of mangroves, invasion of permanent preservation areas, the disordered occupation of soil, and replacement of native vegetation. Such anthropic interferences can, directly or indirectly, affect water quality and the maintenance of important ecosystem services delivered by the community of primary producers.

Given the knowledge gap regarding marine microalgae in large areas of the coast of Bahia, this is the first floristic survey of the marine phytoplankton community in the southern coast of State. This work was developed to characterize the composition and distribution of microphytoplankton in this region.

\section{Material and Methods}

\section{Studied area}

The southern coast of Bahia (Fig. 1) has an extension of $\sim 120 \mathrm{~km}$, characterized by a fairly irregular coastline (Bittencourt et al. 2000). The climate of the region is tropical humid, with an average temperature of $25^{\circ} \mathrm{C}$ and abundant rainfall $\left(\sim 1,700\right.$ to $\left.2,500 \mathrm{~mm} \mathrm{year}^{-1}\right)$, which is more concentrated from March to June (Bittencourt et al. 2000; Fischer et al. 2007; Amorim et al. 2011). The Brazil Current is the predominant water mass in the region, which confers to the area its oligotrophic characteristic (Rezende et al. 2011).
Data sampling and analysis

Sampling took place at three sites: Morro de São Paulo, Boipeba (both inside the APA Tinhare-Boipeba), and Barra Grande (APA Baía de Camamu) (Fig. 1), with three points sampled at each site, in December 2013 and May 2014 (Tab. 1). At each collection point, the temperature and salinity were measured in situ using a multiparameter probe (Hanna HI 9829, São Paulo, Brazil). The water transparency was estimated using a Secchi disc. At each collection site, 250 $\mathrm{mL}$ water samples were collected by a horizontal dredger using a plankton net $(20 \mu \mathrm{m}$ mesh size $)$ to study the phytoplankton community composition. Additionally, $1 \mathrm{~L}$ water (in triplicate per point) was collected from the subsurface using Van Dorn bottle for quantitative analyses. All samples were stored in dark polyethylene flasks and fixed with lugol 1\%.

Qualitative analyses (18 plankton net samples) were carried out by observations on slides, under a light microscope (Olympus CX31, Tokyo, Japan). The samples were cleaned with $\mathrm{H}_{2} \mathrm{O}_{2}$ and distilled water, especially for better visualization the frustules of diatoms. The taxa were identified based on the specialized literature (e.g., Cupp 1943; Cleve-Euler 1955; Wood 1968; Dodge 1985; Balech 1988; Hernández-Becerril 1996; Tomas 1997; Tiffany \& Hernández-Becerril

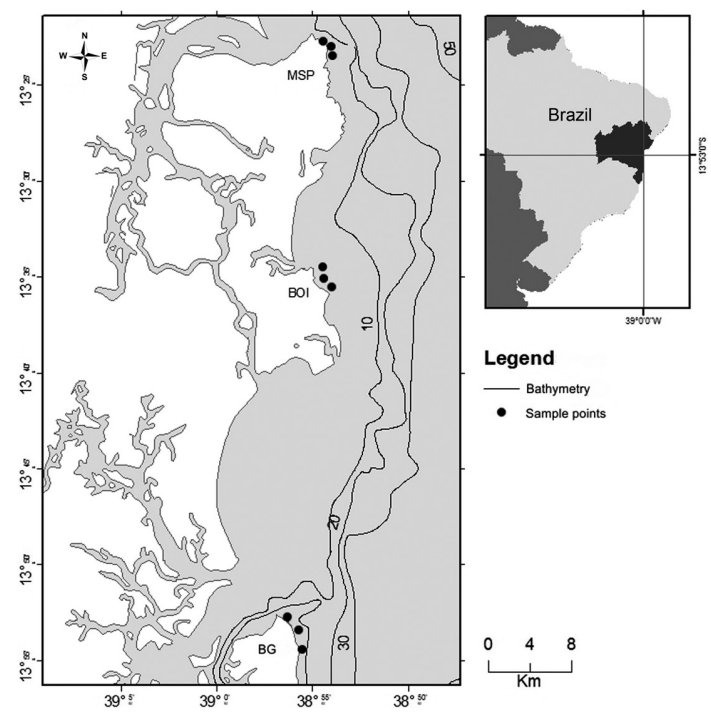

Figure 1 - Map showing the sampling sites (nine sample points) along the southern coast of Bahia. $($ MSP $=$ Morro de São Paulo; BOI = Boipeba; $\mathrm{BG}=$ Barra Grande). 
Table 1 - Hydrological variables, Shannon-Weaver Index (H') and Pielou Equability (J') from sampling sites. (MSP = Morro de São Paulo; BOI = Boipeba; BG = Barra Grande).

\begin{tabular}{lcccccc}
\hline Region & Dates & Temperature $\left({ }^{\circ} \mathbf{C}\right)$ & Salinity & Transparency $(\mathbf{m})$ & $\mathbf{H}^{\prime}\left(\mathbf{b i t s ~}^{\text {ind }} \mathbf{1}^{-1}\right)$ & $\mathbf{J}^{\prime}$ \\
\hline \multirow{2}{*}{ MSP } & $2013 / 02 / 12$ & $27.7 \pm 0.2$ & $33 \pm 0.5$ & $5.5 \pm 1.3$ & 3.9 & 0.8 \\
& $2014 / 15 / 05$ & $26.0 \pm 0.5$ & $32 \pm 0.5$ & $4.5 \pm 0.5$ & 4.0 & 0.8 \\
\hline \multirow{2}{*}{ BOI } & $2013 / 03 / 12$ & $28.3 \pm 0.2$ & $33 \pm 0.1$ & $5.2 \pm 1.0$ & 3.8 & 0.8 \\
& $2014 / 16 / 05$ & $26.0 \pm 0.5$ & $32 \pm 0.5$ & $4.5 \pm 1.0$ & 4.0 & 0.7 \\
\hline \multirow{2}{*}{ BG } & $2013 / 18 / 12$ & $28.5 \pm 0.5$ & $31 \pm 0.8$ & $5.0 \pm 0.5$ & 4.0 & 0.8 \\
& $2014 / 28 / 05$ & $26.5 \pm 0.2$ & $30 \pm 0.5$ & $4.5 \pm 1.0$ & 3.8 & 0.7 \\
\hline
\end{tabular}

2005; Tenebaum 2006; Throndsen et al. 2007), and were observed as many slides as needed in each sample, until no new species were added to the checklist. We used the taxonomic classification system of Guiry \& Guiry (2017).

The quantitative analyses ( 54 bottle samples) was according to the Utermöhl method (1958) order to determine the phytoplankton cell concentration (cell $\mathrm{L}^{-1}$ ); we used 50 or $100 \mathrm{~mL}$ sedimentation chambers, depending on the sample; and counted the entire bottom area of the chamber using an inverted microscope (Motic AE 2000, Hong Kong, China) at 200 to $400 \mathrm{X}$ magnification.

The phytoplankton community was characterized by measuring the richness (S), the Shannon diversity index (H') and the Pielou species evenness (J'). The phytoplankton cell concentration from different locations were analyzed with the Kruskal-Wallis analysis of variance, after checking the assumptions for parametric analyses (normality and homoscedasticity) using the Shapiro-Wilk and Levene tests. Following, the multiple value comparison test was used to assess significant differences $(p<0.05)$ in the cell concentration between sites. All statistical analyses were carried out in an R environment ( $\mathrm{R}$ Core Team 2016).

The frequency of occurrence of the taxa was calculated based on Matteucci \& Colma (1982), considering the number of samples in which a given taxon occurred in relation to the total number of collected samples (plankton net and bottle). The following categories were used: very frequent (VF) $>70 \%$; frequent $(\mathrm{F})>40 \% \leq 70 \%$; infrequent (I) $>10 \% \leq 40 \%$; sporadic or rare $(\mathrm{S})<10 \%$.

Samples were deposited in the Herbarium Alexandre Leal Costa of the Universidade Federal da Bahia (ALCB, UFBA), Bahia - Brazil (S1 in supplementary material <https://doi.org/10.6084/ m9.figshare.9759311.v1>).

\section{Results and Discussion}

The hydrological pattern of the southern coast of Bahia is divided into a dry season, between August and February, and rainy season, from March to July (Bittencourt et al. 2000; Fischer et al. 2007; Amorim et al. 2011). However, there were no large variations in water temperature $\left(28 \pm 0.4\right.$ and $\left.26 \pm 0.5^{\circ} \mathrm{C}\right)$, salinity $(34 \pm 1.5$ and $32 \pm 2)$ and transparency $(5 \pm 1$ and $4 \pm 0.6 \mathrm{~m})$ between December (dry) and May (rainy) months, respectively (Tab. 1).

A total of 149 taxa were identified, distributed in six phyla: Bacillariophyta - class Bacillariophyceae (50 taxa), Coscinodiscophyceae (14 taxa) and Mediophyceae (19 taxa); Miozoa - class Dinophyceae (50 taxa); Cyanobacteria class Cianophyceae (9 taxa); Euglenophyta - class Euglenophyceae (3 taxa); Haptophyta - class Coccolithophyceae (2 taxa) and Raphidophyceae (1 taxa); Ochrophyta - class Dictyochophyceae (1 taxa) (S2 in supplementary material $<$ https://doi. org/10.6084/m9.figshare.9759311.v1>).

Diatoms (about 63\%) and dinoflagellates (about 26\%) were the most representative groups in the specific composition, and marine species predominated in both periods, following a pattern typically found in coastal waters and in the Brazilian continental shelf (e.g., Fernandes \& Brandini 2004; Lacerda et al. 2004; Procopiak et al. 2006; Rezende et al. 2015).

The area with the highest richness was MSP (109), followed by BOI (101) and BG (98). All three areas showed exclusively occurring taxa: 20 in BG, 16 in MSP and 13 in BOI 
(S2 in supplementary material <https://doi. org/10.6084/m9.figshare.9759311.v1>). The microphytoplankton species diversity index in the southern coast of Bahia has between 3.8 and 4 bits ind $^{-1}$, and there was no dominance of any taxon (J' 0.8) (Tab. 1). The indexes of phytoplankton diversity characterize the system as having high diversity, according to Margalef (1978) classification; they were similar to those found in other coastal and estuarine regions of Brazil (e.g., Matta \& Flynn 2008; Santiago et al. 2010; Affe \& Santana 2016).

The phytoplankton cell density ranged from $1.85 \times 10^{5}$ cells $\mathrm{L}^{-1}$ in Boipeba to $1.12 \times 10^{6}$ cells $\mathrm{L}^{-1}$ in Morro de São Paulo, and did not differ significantly among the three regions $(p=0.19)$, nor between the collection periods $(p=0.58)$.

Regarding frequency of occurrence, 72 species were considered infrequent, 32 species were considered very frequent, 33 species were considered frequent, and 12 species were considered sporadic. The high diversity was due to the large contribution of infrequent taxa (48\%), especially diatoms with elongated frustules (e.g., Nitzschia, Pleurosigma) and dinoflagellates of epibenthic habitats (e.g., Ostreopsis, Prorocentrum) occasionally recorded on the surface due to intense resuspension processes. Among the frequent $(22 \%)$ and very frequent (32\%) taxa, chain-forming diatoms (e.g., Bacillaria, Bacteriastrum, Chaetoceros) were highlighted as an important survival strategy in waters with high hydrodynamics (Hendey 1964; Margalef 1978; Round et al. 1990).

In the current floristic survey, new records were revealed for the Brazilian coast. Based on the list of Brazilian flora (BFG 2018), five taxa are indicated as new records for the Brazilian coast: Gyrosigma angulatum (Quekett) Griffith \& Henfrey Cleve, Melosira nummuloides C. Agardh and Navicula lyroides Hendey (Bacillariophyta), Ostreopsis cf. siamensis Johs. Schmidt and Prorocentrum robustum Osorio-Tafall (Miozoa). Sixteen taxa are new records for the Northeastern Brazilian coast: Cymbopleura naviculiformis (Auerw.) Krammer, Cocconeis placentula (Ehrenberg), Corethron criophilum Castracane, Coscinodiscus wailesii Gran \& Angst, Diploneis didyma (Ehrenberg) Ehrenberg, Gyrosigma littorale (W.Smith) Griffith \& Henfrey, Leptocylindrus minimus Gran and Nitzschia sigmoidea (Nitzsch) W. Smith (Bacillariophyta), Cyclotella litoralis Lange \&
Syvertsen, Dinophysis amandula (Balech) Sournia, Prorocentrum cf. mexicanum Osorio-Tafall, Protoperidinium ovum (Schiller) Balech (Miozoa), Komvophoron schmidlei (Jaag) Anagnostidis \& Komárek (Cyanobacteria), Chattonella subsalsa B. Biecheler and Dictyocha fibula Ehrenberg (Ochrophyta), and Eutreptia cf. viridis Perty (Euglenophyta). Also, 27 taxa are new records for the coast of Bahia: 22 Bacillariophyta (S2 in supplementary material <https://doi.org/10.6084/ m9.figshare.9759311.v1>), Gonyaulax spinifera (Clap. \& Lachm.) Diesing, Phalacroma cf. rapa Jorg., Protoperidinium pentagonum (Gran) Balech, and Protoperidinium cf. venustum (Matzenauer) Balech (Miozoa), besides Trichodesmium thiebautii Gomont ex Gomont (Cyanophyceae).

Although between 2010 and 2015 Bahia was one of the seven Brazilian states with the highest number of new records of microalgae species (Menezes et al. 2015), the knowledge on marine microalgal biodiversity remains relatively low. Here we presented the results of the first floristic survey carried out in this area which represents the largest coast of Brazil, adding a series of new occurrences of species. Thus, it increases the knowledge on the composition of marine phytoplankton in the Brazilian coast.

\section{Acknowledgments}

This research has been financial supported by the Fundação de Amparo à Pesquisa do Estado da Bahia (FAPESB, No. RED0006/2012). JMCN acknowledges Conselho Nacional de Desenvolvimento Científico e Tecnológico (CNPq \# 307368 / 2015-7) for a Productivity Scholarship in Research.

\section{References}

Affe HMJ \& Santana RMC (2016) Fitoplâncton em áreas de cultivo de ostras na Baía de Camamu, Bahia: investigação da ocorrência de microalgas tóxicas. Novas Edições Acadêmicas, Saarbrücken. 81p.

Amorim FN, Cirano M, Soares ID \& Lentini CAD (2011) Coastal and shelf circulation in the vicinity of Camamu Bay (14요 $)$, Eastern Brazilian Shelf. Continental Shelf Research 31: 108-119.

Baiardi A \& Teixeira FO (2010) Desenvolvimento dos territórios do Baixo Sul e do litoral sul da Bahia: a rota da sustentabilidade, perspectivas e vicissitudes. Relatório de Consultoria Instituto Arapyaú, Salvador. 70p.

Balech E (1988) Los dinoflagelados dell atlántico sudoccidental. Instituto Español de Oceanografia, Plublicaciones especiales, Madri. 219p. 
BFG - The Brazil Flora Group (2018) Brazilian Flora 2020: innovation and collaboration to meet Target 1 of the Global Strategy for Plant Conservation (GSPC). Rodriguésia 69: 1513-1527.

Bittencourt ACSP, Dominguez JML, Martin L \& Silva LR (2000) Patterns of sediments dispersion coastwise the state of Bahia - Brazil. Anais da Academia Brasileira de Ciências 2: 271-287.

Cleve-Euler A (1955) Diatomeen von Schweden und Finland. Alquimist, Wiksells Boktryckeri, Stockholm. 232p.

Cloern JE \& Jassby AD (2010) Patterns and scales of phytoplankton variability in estuarine-coastal ecosystems. Estuaries Coasts 33: 230-241.

Cowgill UM (1987) Changes in nitrogen, phosphorus and phytoplankton composition during the past decade in the Bay of Aratu, Salvador, Bahia, Brazil. Archiv fuer Hydrobiologie 111: 1-14.

Cupp EE (1943) Marine plankton diatoms of the west coast of North America. Press 1: 1943. University of California, London. 237p.

Dodge JD (1985) Atlas of dinoflagellates. A scanning electron microscope survey. Ferrand press, London. $119 \mathrm{p}$.

Eskinazi-Leça E, Koening ML \& Silva-Cunha MGG (2004) Estrutura e dinâmica da comunidade fitoplanctônica. In: Eskinazi-Leça E, NewmannLeitão S \& Costa MF (org.) Oceanografia um cenário tropical. Edições Bagaço, Recife. Pp. 353-373.

Fernandes LF \& Brandini FP (2004) Diatom associations in shelf waters off Parana state, Southern Brazil: annual variation in relation to environmental factors. Brazilian Journal of Oceanography 52: 19-34.

Fischer F, Nascimento A, Pierine C, Fischer CM, Fischer F, Rocha L, Matos LB, Santana L, Vinhares L, Santos MEP, Brito MR \& Santos Filho NG (2007) Baixo Sul da Bahia: uma proposta de desenvolvimento territorial. Projeto Series Editorial CIAGS. CIAGS/UFBA, Salvador. 224p.

Guiry MD \& Guiry GM (2017) AlgaeBase. Worldwide electronic publication, National University of Ireland, Galway. Available at <http://www. algaebase.org $>$. Access on July 2017.

Hernández-Becerril DU (1996) A morphological study of Chaetoceros species (Bacillariophyta) from the plankton of the Pacific Ocean of Mexico. Bulletin of National History Museum of London, Londres 26: $1-73$.

Hendey NI (1964) An Introductory account of the smaller algae of British coastal waters. Part. V: Bacillariophyceae (diatoms). Her Majesty's Stationary Office, London. 137p.

Lacerda SR, Koening ML, Neumann-Leitão S \& FloresMontes MJ (2004) Phytoplankton nyctemeral variation at a tropical river estuary (Itamaracá Pernambuco - Brazil). Brazilian Journal of Biology 64: 81-94.
Mafalda Jr.PO, Souza PMM \& Silva EM (2003) Estrutura hidroquímica e biomassa planctônica no norte da Baía de Todos os Santos, Bahia, Brasil. Tropical Oceanography 30: 31-51.

Magalhães EMMM \& Barbosa WFA (2008) Densidade fitoplanctônica na zona litorânea da Baía de Todos os Santos In: Queiroz AF \& Celino JJ (org.) Avaliação de ambientes na Baía de Todos os Santos: aspectos geoquímicos, geofísicos e biológicos. Proamb, Salvador. 300p.

Margalef R (1978) Life-forms of phytoplankton as survival alternatives in an unstable environment. Oceanologica Acta 1: 493-509.

Matta MEM \& Flynn MN (2008) Estrutura da comunidade fitoplanctônica no gradiente de salinidade do estuário de Cananéia - SP. Revista Intertox de Toxicologia, Risco Ambiental e Sociedade 1: 59-69.

Matteucci SD \& Colma A (1982) Metodología para el estudio de la vegetación. Washington: Secretaria General de la Organización de los Estados Americanos. Programa Regional de Desarrollo Cientifico y Tecnológico, Washington. 168p.

Menezes M, Bicudo CEM, Moura CWN, Alves AM, Santos AA, Pedrini AG, Araújo A, Tucci A, Fajar A, Malone C, Kano CH, Sant'Anna CL, Branco CZ, Odebrecht C, Peres CK, Neuhaus EB, Eskinazi-Leça E, Aquino E, Nauer F, Santos GN, Amado Filho GM, Lyra GM, Borges GCP, Costa IO, Nogueira IS, Oliveira IB, Paula JC, Nunes JMC, Lima JC, Santos KRS, Ferreira LC, Gestinari LMS, Cardoso LS, Figueiredo MAO, Silva MH, Barreto MBBB, Henriques MCO, Cunha MGGS, Bandeira-Pedrosa ME, Oliveira-Carvalho MF, Széchy MTM, Azevedo MTP, Oliveira MC, Cabezudo MM, Santiago MF, Bergesh M, Fujii MT, Bueno NC, Necchi Jr. O, Jesus PB, Bahia RG, Khader S, Alves-da-Silva SM, Guimarães SMPB, Pereira SMB, Caires TA, Meurer T, Cassano V, Werner VR, Gama Jr. WA \& Silva WJ (2015) Update of the Brazilian floristic list of Algae and Cyanobacteria. Rodriguésia 66: 1047-1062.

Peixinho VMC, Paredes JF \& Simas EMP (1980) "Standing crop" na área estuarina SW da Baía de Todos os Santos. Boletim do Instituto Oceanográfico 29: 283- 289.

Procopiak LK, Fernandes LF \& Moreira Filho H (2006) Diatomáceas (Bacillariophyta) marinhas do Paraná, Sul do Brasil: lista de espécies com ênfase em espécies nocivas. Biota Neotropica 6: 1-28.

R Core Team (2016) R: a language and environment for statistical computing. R Foundation for Statistical Computing, Vienna, Austria. Available at $<$ https:// www.R-project.org/>.

Reynolds CS (2006) The ecology of phytoplankton. Cambridge University Press, Cambridge. 535p.

Rezende LF, Silva PA, Cirano M, Peliz A \& Dubert J (2011) Mean Circulation, Seasonal Cycle, and Eddy Interactions in the Eastern Brazilian Margin, a 
Nested ROMS Model. Journal of Coastal Research 27: 329-347.

Rezende KRV, Hatherly MMF, Pimenta CMM, Eduardo J, Vianna SC \& Mangiavacchi N (2015) Phytoplankton community structure in one sector of Guanabara Bay (RJ, Brazil) during 2011 and 2012. Brazilian Journal of Oceanography 63: 239-254.

Round FE, Crawford RM \& Mann DG (1990) The diatoms: Biology and morphology of the genera. Cambridge University Press, Cambridge. 747p.

Santana RMC \& Affe HMJ (2016) Composição e biomassa da comunidade fitoplanctônica no estuário do rio Maraú- Baía de Camamu (BA). Novas Edições Acadêmicas, Saarbrücken. 67p.

Santiago MF, Silva-Cunha MGGS, Neumann-Leitão S, Costa KMP, Palmeira GCB, Porto Neto FF \& Nunes FS (2010) Phytoplankton dynamics in a highly eutrophic estuary in tropical Brazilian. Journal of Oceanography 58: 189-205.
Tenebaum DR (2006) Dinoflagelados e tintinídeos da região central econômica exclusiva brasileira: guia de identificação. Museu Nacional (Série livros 15), Rio de Janeiro. 288p.

Throndsen J, Hasle GR \& Tangen K (2007) Phytoplankton of Norwegian coastal Waters. Almater Forlag AS, Oslo. 343p.

Tiffany MA \& Hernández-Becerril DU (2005) Valve development in the diatom family Asterolampraceae H.L. Smith 1872. Micropaleontology 51: 217-258.

Tomas CR (1997) Identifying marine phytoplankton. Academic Press, San Diego. 858p.

Utermöhl H (1958) Zur Vervolkommung der quantitativen phytoplankton-methodik. Internationale Vereiningung fuer Theoretische und Angewandte Limnologie 9: 1-38.

Wood EJF (1968) Dinoflagellates of the Caribbean Sea and adjacent areas. University of Miami Press, Coral Gables. Pp.135-139. 